\title{
Women Participation in Health Sector Development Planning in Jayapura Regency, Indonesia
}

\author{
S Fatimah ${ }^{1}$, Rakhmat $^{2}$, Hasniati $^{3}$, M Yunus $^{4}$ \\ ${ }^{1}$ Universitas Yapis Papua, Jayapura, ${ }^{2,3,4}$ Universitas Hasanuddin, Makassar \\ ${ }^{1}$ sitifatimah@uniyap.ac.id, ${ }^{2}$ hrakhmat63@gmail.com, ${ }^{3}$ hasniati@unhas.ac.id, \\ 는
}

\begin{abstract}
This study of National Health System becomes a reference in the preparation and implementation of health development in Indonesia. Related to the health development of an area or region, the government sets public health standards. For the Papua region, particularly Jayapura Regency in general the health status has not yet reached the national health standard. One indicator on the national life expectancy is 69.19 years old while in Jayapura the life expectancy is only 66.4 years old. The low health standard cannot be separated from community participation, especially women in the development planning process in the health sector. To assess the active involvement of women in development can be seen from the Gender Development Index (IDG) data. The IDG of Jayapura Regency is at the level of 61.91 lower than that of the neighboring district, Sarmi Regency at 65.29 and Keerom Regency at 62.34. Even though the two regencies are a division area of Jayapura Regency. This shows that Jayapura Regency women have not been fully involved directly in health development planning activities in Jayapura Regency. The question then is what causes the low participation of women in regional development planning? To answer these questions, this study uses a qualitative research approach. Data collection techniques are in-depth interviews and focus group discussions (FGDs) to actors involved in the development planning consultation process (Musrenbang) in Jayapura Regency. While the data analysis technique of this research is by classification, categorizing, and clarifying data. The results showed that the cause of the low participation of women in the development planning process in Jayapura was due to three factors namely lack of access, cultural barriers and healthy issues was not major focus.
\end{abstract}

Keywords: development, health, Jayapura, participation, women

\section{INTRODUCTION}

Corruption Health development has been made a legal force in Presidential Regulation Number 72 of 2012 concerning the National Health System (SKN). In Article 1 point 2 of the policy it is explained that the National Health System (SKN) is a health management carried out by all components of the Indonesian people in an integrated and mutually supportive manner to guarantee the highest possible level of public health. The National Health System becomes a reference in the preparation and implementation of health development that starts from planning, monitoring and evaluation activities. Manifestation of the previous policy, health development is carried out based on the Healthy Indonesia Program which has been planned for 
achievement through the Strategic Plan of the Ministry of Health in 2015-2019, established through Minister of Health Decree Number HK.02.02 / Menkes / 52/2015.

For the Papua region, particularly Jayapura Regency in general the health status has not yet reached the national health standard. One indicator on the national life expectancy is the standard age of 69.19 years while in Jayapura the new age reaches 66.4 years. Social and economic context cannot be separated from the health standard of particular area. Papua compairing with the other main islands in Indonesia are lacking on infrastructures, affordable medical price for society and other supporting conditions that can contribute to the health of the society itself. Therefore, this research will examine further about the lower standard of life expectancies in Jayapura than national standard through qualitative approach.

The low health standard cannot be separated from community participation, especially women in the development planning process in the health sector. The approach of women in development that emerged in 1960s that centralized the role of women in every aspects of development globally became crucial particularly to examine whether inclusive approach involved women as the active subjects. However behind that genuine idea that positioning women in central subjects in development, some works exhibited findings that the interrelations between women and development are probably too weak to be self-sustaining [1]. Nonetheless, some of other works shared a optimistic view on this matters [2]-[4].

To assess the active involvement of women in development can be seen from the Gender Development Index (IDG) data. The IDG of Jayapura Regency is at the level of 61.91 lower than that of the neighboring district, Sarmi Regency at 65.29 and Keerom Regency at 62.34. Whereas the two regions (Sarmi Regency and Keerom Regency) are the expansion areas of Jayapura Regency as the parent region. Therefore, to tackle this issue, it needs a comprehensive cooperation within stakeholders, from central government to the lowest local level of government in the villages area.

This problem occurs due to the lack of a good development planning system at the level of district government. Health development planning activities in Jayapura Regency, apparently did not optimally involve women's participation, so health development programs and activities that were designed were not based on data and information on women's health needs. This illustrates that Jayapura Regency women have not been fully involved directly in health development planning activities in Jayapura District. The question then is what causes the low participation of women in regional development planning?

Some findings revealed in this research namely fristly, the limited invitation to women to attend regional development planning meetings (musrenbang). Besides that, women are also limited in accessing information related to musrenbang. Secondly, in Papuan culture, women's groups are considered as second class who do not have the right to speak in the forum so that women become passive when attending regional development planning meetings (Musrenbang). Thirdly, the Musrenbang discusses more about the infrastructure sector than the health sector. Even if it discusses the health sector, it only focuses on the construction of health infrastructure such as the construction of community health centre buildings (puskesmas or posyandu). Each of this finding will be explained in the discussion sphere after the reseach method.

\section{RESEARCH METHOD}

This study uses qualitative methods to seek answers about women's participation in development planning in the health sector, and the determinants related to women's participation models in health sector development planning in Jayapura District, so the type of research used 
is descriptive, that is the type of research that describes phenomena or events as it is. Data collection techniques are in-depth interviews and focus group discussions (FGDs) to actors involved in the development planning consultation process (musrenbang) in Jayapura Regency. While the data analysis technique of this research is by classification, categorizing, and clarifying data. Furthermore, the results of this research can hopely contribute to the working tools of gender based planning analysis particularly in Jayapura regency.

\section{RESULTS AND DISCUSSION}

Development planning is very important because it determines the direction of development of an area. Development planning is the initial stage of the community involved in the development process. Moreover, on the side of public policy and administration the involvement and participation of society to the making of policy are vital and important in order to strengthen and control the policies efficiently. The humanity values as the universal value situated in the core of public policy and administration.

Based on Yeremias explanation that administration by public is a concept that directing orientation to the society empowerment, independency and capacities. The community participation in this sense can create independency within the society that to some extent would be reduced the government burden in some areas[5]. Rosenbloom also stated that "public administrators should be more responsive to citizens and should be more responsive to citizens and should focus their responsibility to serve and empower citizens as they manage public organizations and implement public policy" [6]. Mostly works would be supporting the positive notion on society participation on public policy and administration or public private partnership in public administration [7]-[12]. However the citizen participation in decision making produced either positive/success or negative/fail due to particular environment and social context [13]. From several views on community participation shared some points that addressing in the ideal, practical, conceptual and realities among the topics that locating values such as transparency, responsible, fair, law enforcement, consensus, and pro-poor as the central features in order to making a good governance based on community active involvement.

In Indonesia context, community involvement in the development planning process can be seen in the Musrenbang forum, a program that officially established by the central government which run on the local level. The initial idea was as simple as the notion/plan from bottom/grass root level can be leveraged to the upper level/regencies/provinces. However, practically, the initial idea or design did not come from below but a designed plan from upper level either regency or province to the grass root level. It seems like a dissemination program rather than scooping up public opinion or plan.

In the Musrenbang forum, recommendations were made for program proposals that would later become a reference for development planning policies in Jayapura Regency. In planning the development of women's participation, it can be seen from the activeness of women who contribute their thoughts so that the implementation of development programs is carried out appropriately and attend meetings or anything related to village or district development.

To determine the development program in the musrenbang forum, three stages are passed, namely the village level musrenbang forum, the district musrenbang forum and the regency level musrenbang forum. All the musrenbang levels discuss 5 sectors namely the infrastructure sector, the economic sector, the health sector, the socio-cultural sector and finally the education sector. This research focuses on the health sector.

The results of the study stated that development planning in the Musrenbang forum was based on regulations, where the community was actively involved in the Jayapura Regency 
Musrenbang forum. As stated by one of the key informants from the Regional Development Planning Agency (Bappeda), it is stated that the Jayapura Regency Government, through Bappeda, is fully in charge of development planning, which involves the community so that the direction of development in the region is in accordance with the wishes of the community. The same thing was stated by a key informant from the Jayapura Regency Health Office stating that the program implemented by the Health Office was a follow-up to the program proposal from the Jayapura Regency Musrenbang forum. However, the Musrenbang planning process in Jayapura Regency seems formalistic, where the participants of the Musrenbang have been determined by the Jayapura Regency Regional Government. During the discussion meeting the proposed development programs were mostly involved from the men, while women were not much involved. Women's participation in development planning in Jayapura Regency shows that women do not have an active role as men in development planning.

This is due to several factors that influence. The following is a description of the factors causing the low participation of women in Jayapura Regency, firstly, limited information and invitations to women's groups. The findings in the field stated that in the process of the Musrenbang forum in Jayapura District, women's groups did not have access to information regarding the schedule for the Musrenbang forum.

This makes women in Jayapura Regency inactive when there is a Musrenbang forum, be it at the village, district level, let alone at the regency level. Besides limited information, women are also limited to accepting invitations to attend the Musrenbang forums. Invitations are only addressed to the head of the family welfare education (PKK) who is also the wife of the village head or district head. While housewives did not get an invitation. In fact, all programs related to health issues are specifically women who had better understand of health issues. This has caused development programs in Jayapura Regency to be suboptimal.

It can be analysed slow but sure the access condition regarding invitation to attend meeting will be segregated the women in Jayapura regency. The invitation to the women whose had position and some key important status that inclusive for women commonly. Moreover, that would become the obstacles of flows of information from reaching wider audiences of health devoplment in Jayapura regency. In addition, due to this condition, women who are not regularly invited to the meetings also act passively. In the other name, passive is not something natural than construct of condition in society itself. Therefore, it is weakening the health knowledge for the common people particularly women.

This is not local pattern, but global pattern. As North explained "social order fundamentally different logic than the open access order logic. A common feature of limited access is that political elites control the economy, each getting some share of the rents"[14]. In this topic, the rents can be manifested in the access of information. In the word of Larson, it can be result in a general health disparities [15]. Thus, the disparity in information can be affected the health of people in society empirically just because the insufficient knowledge of health itself.

Secondly, this research found there a significant correlation between women and papuan culture. The portraits of Papuan women in general are still second class/citizen in society. The gender construction was crystalized from centuries that emphasizing male dominant role in society. This is inevitable from the cultural characteristics in Papua which are divided into 7 (seven) indigenous territories with \pm 500 languages having their own perspectives on women in each customary area. When viewed from culture, in general the values of culture and religion that are believed by the people of Papua, tend to harm the position of women. Culture places women as objects of men while religion views women as men 's companions. In the Papuan 
tradition, women are considered outsiders, because after marriage they will come out of their environment, and also women are outsiders of all forms of customary decision making.

Women are placed not as a single individual but only as an extension of men's interests and needs. In addition, the role of Papuan women by cultural values in each customary area is indeed often placed only around wells, mattresses and kitchens. women are positioned as individuals who meet consumption and sex needs in the family. This is what makes women in Jayapura Regency not all who want to talk or express their opinions in the musrenbang forum. They are also still many who are reluctant to talk because they are still shy and have not been able to ventured to express their opinions. Even though, when they attended the meeting, they became an object of audience not active speakers that articulating their own problems mainly when male dominated the discussion. The women perception, if men have talk during the session, they have to listen and problem solved by itself.

Therefore, this cultural condition which portraits women as passive objects became obstacles of health issues. Women cannot express their own problems since whereas the women are the most suffer from many health issues beside children.

Thirdly, this research found the meeting Musrembang mostly talking about infrastructure plans. The health issues became marginal. Moreover, the topic of discussion of male-dominated paid less attention to the women problems. It seems like when the men talking about infrastructure, they were talking about the masculinity imagination projects.

When women are restricted from access to information and invitations to attend the musrenbang forums and the influence of Papuan customs which dominates men in the musrenbang forums. In the Musrenbang forum, most of the discussion concerns infrastructure. Although it has been determined that there are 5 areas to be discussed in the forum. The perspective adopted by Musrenbang participants is physical development planning while nonphysical nature is sometimes ignored. Likewise, when discussing the health sector, the direction of the discussion always concerns the infrastructure of health facilities and infrastructure, not the preconditions around the health issues itself. Furthermore, the agenda setting of health issues became more difficult since women did not get a strategic position to articulate the issues and cultural barriers that construct mind when women too active speaks would ruin the meetings.

Several works have done speaking about the infrastructure as the project of masculinity. Olofsdotter explained that masculinities are reproduced in project-based organizations in everyday work practices [16]. Siemiatycki stated that unequal gender dynamics are a key feature of the production of infrastructure deeply embedded in the organizational structures, symbolic narratives, employment practices and system of power[17]. The needs of government to advance their knowledge about gender sensitivity related development became the crucial point that able government to leverage their achieveness.

\section{CONCLUSIONS}

Results of this research came from three important findings namely lack of information access, cultural barriers and meeting focus. The lack of information access initially came from the selection of invitation which was not inclusive for all women equally. Cultural barriers came from society habitual discourse that positioned women as the second-class citizen. Male domination in the Musrembang forum control all the discussion. The facts that male domination at the forum was causing such limited chance to put agenda on health because the forum mostly speaking about infrastructure. Therefore, it needs gender mainstreaming on the stakeholders in order to give women more chances to express and articulates their problems and solutions. Thus, based on the results of research and discussion, it can be concluded that women's 
participation in development planning is still low. This is not only the health sector but also other sectors.

\section{REFERENCES}

[1] E. Duflo, "Women empowerment and economic development," Journal of Economic Literature. 2012.

[2] E. Boserup, N. Kanji, S. F. Tan, and C. Toulmin, Woman's role in economic development. 2013.

[3] U. Women, "Gender Equality - Why it Matters," Sustainable Development Goals. 2016.

[4] UN Women, Turning promises into action: Gender equality in the 2030 Agenda for Sustainable Development. 2018.

[5] Y. T. Keban, "Enam Dimensi Strategis Administrasi Publik: Konsep," Teor. dan Isu, Yogyakarta Gava Media, 2004.

[6] D. H. Rosenbloom, "Public administrative theory and the separation of powers," in The Constitutional School of American Public Administration, 2016.

[7] H. A. Simon, D. W. Smithburg, and V. A. Thompson, Public administration. 2017.

[8] S. Grimmelikhuijsen, S. Jilke, A. L. Olsen, and L. Tummers, "Behavioral Public Administration: Combining Insights from Public Administration and Psychology," Public Adm. Rev., 2017.

[9] S. P. Osborne, Z. Radnor, and G. Nasi, "A New Theory for Public Service Management? Toward a (Public) Service-Dominant Approach," Am. Rev. Public Adm., 2013.

[10] D. P. Carpenter and G. A. Krause, "Reputation and Public Administration," Public Adm. Rev., 2012.

[11] J. Forrer, J. E. Kee, K. E. Newcomer, and E. Boyer, "Public-private partnerships and the public accountability question," Public Administration Review. 2010.

[12] J. M. Bryson, B. C. Crosby, and L. Bloomberg, "Public value governance: Moving beyond traditional public administration and the new public management," Public Adm. Rev., 2014.

[13] R. A. Irvin and J. Stansbury, "Citizen Participation in Decision Making: Is It Worth the effort?," Public Administration Review. 2004.

[14] D. North, J. J. Wallis, S. B. Webb, and B. R. Weingast, "Limited Access Orders in the Developing World: A New Approach to the Problems of Development," Policy Res. Work. Pap., 2008.

[15] N. I. Larson, M. T. Story, and M. C. Nelson, "Neighborhood Environments. Disparities in Access to Healthy Foods in the U.S.," American Journal of Preventive Medicine. 2009.

[16] G. Olofsdotter and L. Randevåg, "Doing masculinities in construction project management: 'We understand each other, but she...," Gend. Manag., 2016.

[17] M. Siemiatycki, T. Enright, and M. Valverde, "The gendered production of infrastructure," Prog. Hum. Geogr., 2019. 